\title{
Rüzgâr Eneriisi Santral Yatırımlarının Değerlendirilmesinde Monte Carlo Simülasyonunun Kullanılması
}

Șakir SAKARYA' - Hasan Hüseyin YILDIRIM²

Makale Gönderim Tarihi: 03.03.2017

Makale Kabul Tarihi: 23.09.2017

\section{ÖZ}

Bu çalıșmada, Crystall Ball programı kullanılarak rüzgar enerjisi santral (RES) yatırımlarının değerlendirilmesinde monte carlo simülasyon (MCS) modeli kullanılmıștır. RES yatırımını etkileyen girdi değișkenlerin farklı kombinasyonları simüle edilerek, projenin net bugünkü değeri (NBD) belirlenmeye çalıșılmıștır. Projenin NBD'sine ait değerlendirmede üç farklı senaryodan yararlanılmıștır. Üç farklı senaryo için yapılan simülasyon sonuçlarında RES yatırımının NBD'sine ait MCS analizi sonuçları elde edilmiștir. MCS modelinin RES yatırımlarının değerlendirilmesinde kullanıșlı bir model olduğu sonucuna ulașılmıștır.

Anahtar Kelimeler: Rüzgar Enerjisi Yatırımları, Monte Carlo Simülasyonu, Senaryo Analizi

JEL Sinıflandırması: E27, G31, O22

\section{Using Monte Carlo Simulation For Wind Power Generation Investment's Assessment}

1 Prof. Dr., Balikesir Üniversitesi, IïBF, İșletme Bölümü, sakarya@balikesir.edu.tr orcid. org/0000-0003-2510-7384

2 Öğr. Gör. Dr., Balikesir Üniversitesi, BUBYO, Bankacılık ve Finans Bölümü, hhyildirim@balikesir.edu.tr 


\section{Abstract}

In this study, using Crystall Ball software Monte Carlo Simulation (MCS) Model was used for evaluation of wind power plant (WPP) investment. WPP project's Net Present Value (NPV) were determined, by simulating different combinations of input variables affecting the WPP investments. Three different scenarios were used in the evaluation of the project's NPV. In the simulation results for three scenarios, the results of the MCS analysis of the WPP investment's NPV was obtained. End of the results, MCS is a useful method for the evaluation of the WPP investmet.

Keywords: Wind Power Investment, Monte Carlo Simulation, Senario Analysis

\section{JEL Classification: E27, G31, O22}

\section{GíRiș}

Enerii, dünyadaki birçok değișimin önemli yapı tașlarından biri olmuș ve bu özelliğini de devam ettirmektedir. Enerji ve enerji kaynakları üretimin ve ekonomik yașantının olmazsa olmazlarındandır. Her geçen gün doğal kaynaklara ve eneriiye olan talep artarak devam etmektedir. Bundan dolayı temiz, güvenilir ve sürdürülebilir enerjinin tedarik edilmesi, yirmi birinci yüzyılda insanlığın ilgilendiği ve üzerinde çalıștı̆ı önemli bir konu haline gelmiștir. Günümüz enerji kullanımında ağırlıklı olarak fosil enerji kaynakları tercih edilmektedir. Ancak fosil yakıtların sınırlı olması ve kullanımı sonucunda çevreye bıraktığı salınımlardan dolayı alternatif enerji kaynaklarına yönelim artmıștır. Alternatif enerji kaynakları içerisinde yenilenebilir enerii kaynaklarından biri olan rüzgar enerjisine olan ilgi de son dönemlerde artmıștır. Dünya genelinde rüzgar enerjisinin son on beș yıldaki durumuna bakıldığında; 2000 yılında dünyanın kurulu rüzgar gücü $17.400 \mathrm{MW}$ olup, 2013 yılı hariç günümüze kadar her yıl kurulu güçteki ek kapasite artıșı artarak devam etmiștir. 2015 yılında eklenen rüzgar kurulu gücü 63.467 MW olup yıl sonuna gelindiğinde dünyanın toplam kurulu rüzgar gücü kapasitesi 432.883 MW'tır (GWEC, 2016:11). Türkiye'de de rüzgar enerjisine yönelik yatırımlar 2007 yılından sonra artıș göstermeye bașlamıștır. 2006 yılında 
51 MW'lık rüzgar eneriisi kurulu gücü her yıl artarak devam etmiștir. 2015 yılında Türkiye'de kurulu rüzgar gücü kapasitesi 4.718 MW iken 2016 yılı temmuz ayı itibariyle 5.146 MW seviyesine ulașmıștır (TUREB, 2016:5).

Dünya'da ve Türkiye'de rüzgar eneriisi yatırımlarına yönelik bu artıș dikkat çekicidir. Bu artıșın temel sebebi ihtiyaç duyulan ve her dönem artan enerii talebinin karșılanması için rüzgar enerjiisinin alternatif bir enerji kaynağı olması mıdır? Yoksa rüzgar enerjisi yatırımlarının ekonomik olarak kazançlı olması mıdır? Her iki sorunun yanıı ı RES yatııımlarına olan ilginin açıklayıcısıdır. Bu çalıșmada RES yatırımını etkileyen nakit giriș ve çıkıșlarıyla bir finansal model olușturulmuștur. RES yatııımlarını etkileyen gelir ve giderlere ait değișkenler stokastik olması, yatırımın ekonomik değerlendirmesinde güçlüklere yol açmaktadır. Senaryo analizi ile girdi değișkenlerin farklı değerleri ile yatııımın çıktı değerini belirlenmektedir. Ancak senaryo analizi, çıkłı değișkenin sonucunu etkileyen girdi değișkenlerin çok fazla kombinasyonunu belirlemekte ve çıktı değișkenin senaryo olasılıklarını tespit etmekte yetersiz olmaktadır (Ross vd., 2010:210). Monte carlo simülasyonunda girdi değișkenlerin çok fazla sayıda rassal dağılımı ile tahmin değișkeni sonuçları farklı kombinasyonlarla olușturulmaktadır.

\section{Literatür Araștırması}

Yenilenebilir enerii teknolojilerine olan ilginin artmasına rağmen MCS analizi ile enerii projelerinin değerlendirildiği çalıșmalar henüz istenilen sayıda değildir. RES yatıımlarının ekonomik olarak değerlendirildiği ve konu ile ilgili MCS kullanıldığı çalıșmalardan bir kısmı așağıda verilmiștir.

Desrochers ve Blanchard (1986) yapmıș oldukları çalıșmada rüzgar enerjisinin maliyet etkinliği için 1 yıllık türbine ait saatlik verilerden yararlanmıșlardır. Çalıșmada simülasyonla kurulan method yardımıyla farklı șekillerdeki rüzgar türbinlerinin enerji üretim kapasiteleri karșılaștırılabilmektedir.

Liberman (2003) ise çalıșmasında $A B D^{\prime}$ de farklı eyaletlerden seçilmiș 239 bölgede RES yatıımlarını meteorolojiden alınan rüzgar verilerine bağlı olarak MCS ile bölgeler için geri ödeme 
süresini araștırmıștır. Bölgelerin hakim rüzgar hızlarının farklı olmasından dolayı bölgelerde yapılacak yatırımlara ait geri ödeme süreleri farklı çıkmıștır. Rüzgar hızı fazla olan yerlerde yapılan rüzgar enerji yatırımlarına ait geri ödeme süresi, rüzgar hızı düșük olan yerlere göre daha düșük çıkmıștır.

Madlaner ve Wenk (2008) İsviçrenin kurulu enerji kapasitesini araștırmıșlar ve enerji kaynaklarına ait yatırımların NBD'lerini MCS ile karșılaștırmıșlardır. MCS analizi sonucunda elde edilen çıktılardan yararlanarak enerji kaynak türlerinden belli oranlarda olușturulmuș optimum enerji portföyünü hesaplamıșlardır.

Williams vd. (2008) çalıșmalarında Kuzey Arizona eyaletinde iki farklı bölge için RES yatırımı ve ișletilmesi döneminde sağlanacak faydaları simüle etmișlerdir. Kurulan MCS ile yatırıma ait belirsizlikler tahmin edilmeye çalıșılmıștır. Böylelikle her iki bölge ekonomisi için RES yatırım döneminde ve sonrasında ekonomik aktiviteye sağlayacağı faydalar belirlenmeye çalıșılmıștır.

Ay (2010) çalıșmasında farklı finansman seçeneklerinin rüzgar enerjisi yatırımlarının sonuçlarını nasıl etkilediğini araștırmıștır. Calıșmasında yıpranmayı hesaba katan ve katmayan olarak iki farklı durumda ekonomik değerlendirme yapmıștır. İki farklı durum için ekonomik değerlendirme sonuçları farklı çıkmıștır. Ekonomik değerlendirmede yıpranmanın dikkate alındığı yöntemde nakit akımları yüksek çıkmıștır. Bu nedenle yıpranma yatırımın ekonomik değerlendirilmesinde dikkate alınması gereken önemli bir değișkendir.

Hamamcıoğlu (2010) çalıșmasında rüzgar hızı verilerinden yararlanarak matlab programı yardımı ile RES yatırımını 2 farklı senaryoda NBD, GÖS ve IVO'sunu hesaplamıștır.

Frølunde ve Obling (2010) çalıșmalarında RES yatırımlarının ekonomik değerlemesini "DCF" ve "ROV" yaklașımlarını karșılaștırarak yapmıșlardır. Her iki yöntem de RES yatırımlarının ekonomik değerlendirmesinde bașarılı ve kullanılabilir bir yöntem olduğu sonucuna ulașmıșlardır.

Cardell ve Anderson (2010) çalıșmalarında farklı rüzgar hızlarında üretimdeki maliyetleri simüle etmișlerdir. Çalıșmada oluștu- 
rulan senaryolar sonucunda bölgesel rüzgar üretimi ile rüzgar hızı arasında korelasyonların olduğunu belirlemișlerdir.

Khindanova (2013) çalıșmasında RES yatırımlarının ekonomik değerlemesinde MCS yöntemi kullanarak, stokastik değișkenlerden elektrik fiyatı ve maliyet belirsizliklerini modelleyerek çıtı değișken olan "NPV" değerine ait dağılımı elde etmiștir.

\section{Araștırma Metodolojisi}

\subsection{Analiz Yönetimi: Monte-Carlo Simülasyonu}

Simülasyon, gerçek yașamdaki olayları nümerik bir yöntemle belirlemek için bir model olușturmadır. MCS'de simülasyonun istatistiksel yöntemlerle belirlenmeye çalıșıldığı bir modeldir (Williams vd., 2008:401). MCS yaklașımı, belirsiz olan birden fazla değișkenin birbirini etkilediği durumlar için model olușturmakta kullanılan bir yöntemdir (Roques vd, 2006:5). MCS, alternatif enerji santral teknolojilerinin değerlemesini belirlemekte kullanılan faydalı bir yöntemdir (Khindanova, 2013:94). Ayrıca MCS, enerji santral yatırımlarının risk analizinin yapılmasında yararlı araçlara sahip olduğundan yaygın olarak kullanılmaktadır (Hertzmark, 2007).

Monte Carlo Metodu istatistiksel ve deneysel problemlerin çözümünde girdi değișkendeki rassal sayılar yaklașımı ile çıkı değișkeni belirleme yaklașımıdır (Simkins ve Simkins, 2013:263). Metodun bir probleme uygulanması, problemin tesadüfi sayıları kullanarak simule edilip hesap edilmek istenen parametrenin bu simülasyon sonuçlarına bakılarak yaklașık hesaplanması fikrine dayanır (Hançerlioğulları, 2006:545- 556). Monte Carlo karmașıklık derecesi ne olursa olsun stokastik süreçlerin incelenmesi yöntemidir.

Monte Carlo Simülasyonu așağıdaki adımlardan olușmakładir (Spinney ve Watkins, 1996):

- Modeldeki girdi değișkenlerinin belirlenmesi,

- Modeldeki anahtar girdi değișkenlerin olasılık dağılımlarının ve istatistiksel değerlerinin belirlenmesi,

- Anahtar girdi değișkenler arasındaki ilișkiyi istatistiksel olarak tanımlanması, 
- Değișkenlere ait olușturulan girdi değișkenlerin olasılık dağılımları ile çoklu kombinasyonların gerçekleștirilmesi,

- Son olarak modelde bulunan çıkı değișkenin olasılık dağılımlarının çıkarılması.

Deterministik bir model, girdi değișkenler ile çıkłı değișkenler arasında olan planı verir. MCS, girdi değișkenlerdeki sayıları $\left(X_{1}\right.$ $\mathrm{X}_{2}, \mathrm{X}_{3}, \ldots, \mathrm{X}_{\mathrm{n}}$ ) rastgele farklı kombinasyonlarda kullanarak deterministik olan modeli defalarca değerlendirerek çıkı değișkenleri $\left(Y_{1}, Y_{2}, \ldots, Y_{n}\right)$ belirlemektedir.

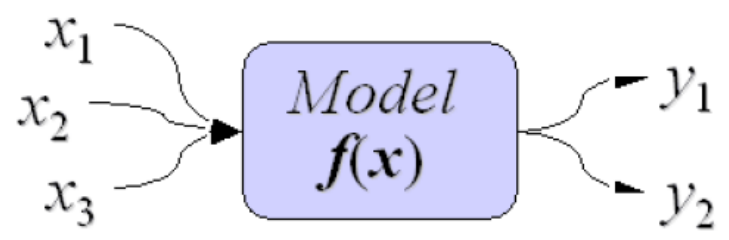

Șekil 1: Modelde Dahil Olan Girdi Değișkenler ve Çıkıı Değișkenler

Bir simülasyon genel anlamda bir modelin binlerce kez değerlendirmesini içerir. Diğer bir ifade ile simülasyonda, girdi değișkenlerin dağılımı dikkate alınarak değișkenlerin farklı konbinasyondan olușan değerleri ile stokastik bir model olușturulur.

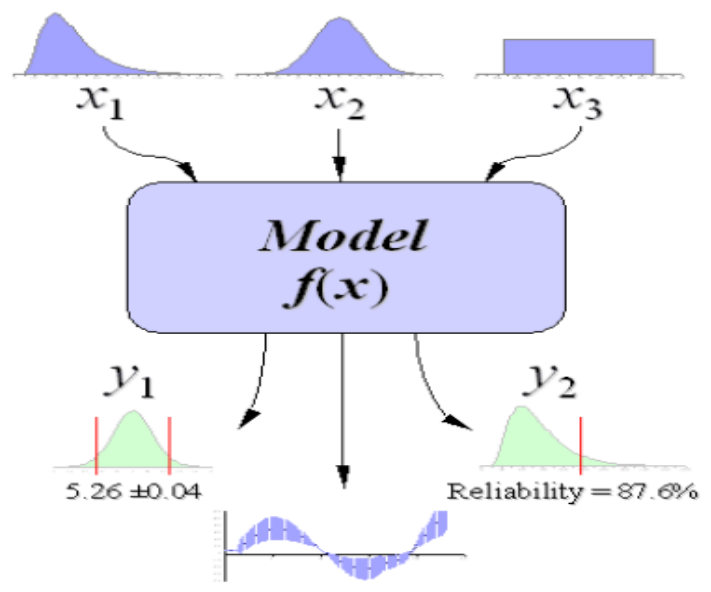

Șekil 2: MCS'nin Temel Prensibi "Stokastik Belirsizlik Dağı̆ımı" 
Simülasyon sonucunda elde edilen tahmini değerler (çıkłı değișkenler) olasılık (veya histogram) dağılımı olarak temsil edilebildiği gibi güvenilirlik tahminleri, hata çizgileri, tolerans değerleri ve güven aralıklarına da dönüștürülebilir. Simülasyon modelleri problemlerin analitik modellerle çözülemeyecek derecede karmașik olduğu durumlarda veya analitik modellerin kurulup, kullanılamadığı durumlarda tercih edilir.

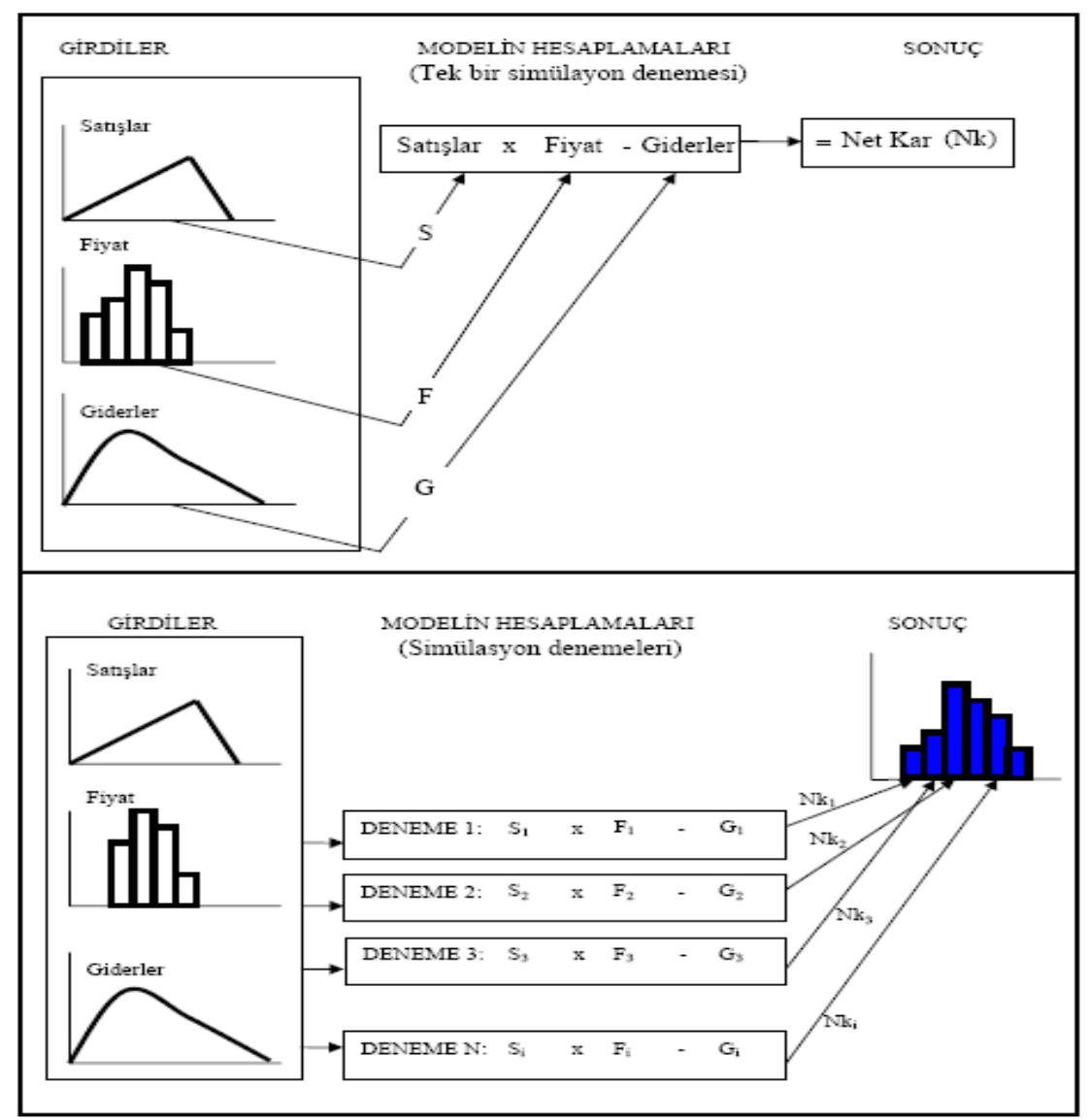

Șekil 3: Monte Carlo Simülasyonunun Çalıșma Biçimi

Günümüzde yenilenebilir enerii yatırımlarının önemli bir oranını rüzgar enerjisi olușturmaktadır. Rüzgar enerjisi yatııılarına bașlanılmadan önce iki temel analize ihtiyaç duyulmaktadır. Bun- 
lardan birincisi teknik analiz olup; yatırım yapılacak yerin, yatırımın kapasitesinin, yatırımda kullanılacak türbin seçiminin vb. teknik unsurlarını içermektedir. İkinci yapılan analiz ise yatırımın finansal olarak analiz edilmesidir ki yatırımın ekonomik olarak kazançlı olup olmadığının belirlenmesidir. Gerek teknik analizde gerekse finansal analizde yatırımı etkileyen ve belirsiz olan birçok değișken vardır. MCS ile bu belirsizliklerin modellemesi yapılarak yatırımın ekonomik analizi değerlendirilmektedir.

Bir rüzgar enerjisi projesinin ekonomik değerlendirilmesinde kurulumun maliyetlerine ait proje tahmini yapılmalıdır. RES yatırımına ait teknik değerlendirmenin ne zaman tamamlanacağı, yatırımın kurulumuna ne zaman bașlanılacağı, yatırımın kurulum süresinin ne zaman tamamlanacağı, yatırımda kullanılacak malzemelerin gelecek fiyatlarındaki değișiklikler, türbin ne kadar süre içerisinde üretici firmadan tedarik edileceği gibi hususlar, RES yatırımında yeterli bilginin olmadığı ve belirsizliklerin olduğu konu bașlıklarıdır. Yatırımın kurulumuna ait maliyetlerdeki belirsizlik durumu, RES yatıımcısı tarafından MCS ile kurulum maliyetlerindeki mümkün olan olasılık aralığı dikkate alınarak gerçekleșebilecek kurulum maliyeti farklı değerlerde belirlenmeye çalıșılmaktadır. Bunun için maliyetlerdeki değișimi belirlerken girdi değișkenlere ait farklı senaryolar, değerler dikkate alınır. Yatırımın ekonomik olarak maliyetteki belirsizlik gibi geliri etkileyen değișkenlerde de belirsizlikler mevcuttur. Belirsizlik içeren her bir girdi değișkene ait olası en iyi durum, normal durum ve kötü durumdaki değerler dikkate alınarak yatırımın farklı durumlarda olası sonuçları belirlenmeye çalıșilmalıdır.

\subsection{Araștırmaya Ait Girdi Parametreleri ve Varsayımları}

RES yatırımında kullanılacak girdi parametrelerine ait değerler, yatırımın Türkiye'de gerçekleștirileceği dikkate alınarak olușturulmuștur. RES yatırımında türbinlerin ekonomik ömrü 25 yıl olarak varsayılmıștır. Yatırıma ait varsayımlar dört bașlık altında toplanmıștır. Bunlar; RES üretimine ait parametreler, RES yatırımına ait maliyetler, RES faaliyetlerinin sürdürülmesine ait giderler, RES yatırımına ait finansal değișkenlerdir. RES yatıımına ait değișkenler 
için üç farklı senaryoya göre değerler olușturulmuștur. Așağıda ekonomik durumun normal olduğu durum dikkate alındığında RES yatırımı için girdi değișkenlerin değerleri verilmiștir.

RES yatırımının üretim parametreleri; yatırım için kurulacak ünite sayısı (türbin sayısı) 30 adettir. Her bir ünitenin kapasitesi 3.3 MW'tır. RES yatırımının toplam kapasitesi 99 MW'tır. Üretim sonucunda elektrik satıșı için YEKDEM'in I Sayılı Cetvelinde yer alan birim elektrik satıșı dikkate alınmıștır. Buna göre birim kw elektrik satıș fiyatı 7,3 cent/Amerikan dolardır.

RES yatırımına ait maliyetler; 3,3 MW'lık bir türbine ait ilk kurulum maliyeti yaklașık olarak 4.000.000 Amerikan dolardır. Illk yatırım maliyetinde kurulum maliyetinin yaklașık olarak \%90'ını türbine ait maliyetler, yaklașık olarak \% 1,5'ini türbinin kurulduğu yerin șalt sahasına ait maliyetler, yaklașık olarak \%3'ünü yatırım için gerekli arazi maliyeti, yaklașık olarak \% 0,5'ini yatırım için proje geliștirme maliyeti, yaklașık olarak \%1'ini diğer maliyetler (yatırım döneminde öngörülemeyen durumlarda gerçekleșen maliyetler), yaklașık olarak \%4'ünü de yatırım için ödenen KDV olușturmaktadır.

RES faaliyetlerinin sürdürülmesine ait yıllık giderler; 30 adet üniteye ait faaliyet giderleri yaklașık olarak 2.400.000 Amerikan dolarıdır. Ünite bașına yıllık gider yaklașık olarak 80.000 Amerikan dolarıdır. RES yatııımının faaliyetlerini sürdürürken katlandığı yıllık maliyetlerin yaklașı olarak \%47'si türbinlerin bakım onarım giderlerinden, yaklașık olarak \% $4^{\prime} \ddot{u}$ çalıșan personel ve güvenlik giderlerinden, yaklașık olarak \% 48'i ünite bașına sistem kullanım ve elektrik kalite giderlerinden ve yaklașık olarak \% 1 'i de diğer operasyonel giderlerden olușmaktadır. Faaliyet giderleri her yıl $\% 1$ oranında artmaktadır.

RES yatırımına ait finansal değișkenler; yatırım finansmanının yabancı kaynak maliyeti için faiz oranı \%7,5 ve özsermaye maliyeti \%12 olarak varsayılmıștır. Yatırım için ihtiyaç duyulan ișletme sermayesi maliyeti ünite bașına 100.000 Amerikan dolarıdır. Türkiye için yıllık enflasyon oranı \%2 olarak varsayılmıșıır. Yatırımın amortisman süresi 25 yıl olarak hesaplanmıștır. Yatırım finansmanında \%50 oranında özkaynak \%50 oranında yabancı 
kaynaktan yararlanıldığı varsayılmıștır. Olușturulan finansal modellemede KDV oranı \%18, Kurumlar Vergisi ise \%20 olarak alınmıștır.

Yukarıda açıklanan parametrelerden yararlanarak Microsoft Office programlarından Excel 2007 programında yatııma ait bir finansal model olușturulmuștur. Finansal modelde yatırımın çıkłı değișkeni olan tahmin değișkeni ve yatırımı etkileyen bağımsız değișkenler Crystal Ball programında analize bașlamadan önce tanımlanmıștır. Ek 1'deki gibi yatırıma ait tahmin değișkeni olarak projenin NBD'si tanımlanmıștır.

Ek 2'de sunulduğu gibi yatırımı etkileyen 7 adet anahtar girdi değișken (bağımsız değișkenler) seçilmiștir. Bunlardan birincisi Euro/Dolar kuru olup ortalama değeri "1.26" ve standart sapması "0.1" olarak tanımlanmıștır. İkinci bağımsız değișken kapasite kullanım oranı olup ortalama değeri "\%40" ve standart sapması "\%4" olarak tanımlanmıștır. Üçüncü bağımsız değișken faiz oranı olup ortalama değeri "\%7,5" ve standart sapması "\%1" olarak tanımlanmıștır. Dördüncü bağımsız değișken ișletme sermayesi ihtiyacı olup ünite bașına ortalama değeri "100.000 Amerikan doları" ve standart sapması "10.000 Amerikan doları" olarak tanımlanmıștır. Beșinci bağımsız değișken özsermaye maliyeti olup ortalama değeri "\%12" ve standart sapması "\%1" olarak tanımlanmıștır. Altıncı bağımsız değișken yıllık faaliyet giderleri toplamı olup ortalama değeri "2.400.000 Amerikan doları" ve standart sapması "240.000 Amerikan doları" olarak tanımlanmıștır. Yedinci bağımsı değișken RES yatırımına ait ilk yatırım maliyetinin toplamı olup ortalama değeri "120.000.000 Amerikan doları" ve standart sapması "12.000.000 Amerikan doları" olarak tanımlanmıștır. Ek 2'deki değerler normal durum senaryosu dikkate alınarak olușturulmuș değerlerdir.

RES yatırımına ait yapılacak simülasyon analizi için yukarıda 7 bağımsız girdi değișken ve dağılımları gösterilmiștir. Simülasyonda bağımsız değișkenleri 10.000 farklı kombinasyonla kurulan finansal modelde çalıștırarak NBD'ye ait sonuçlar ortaya konulacaktır. 


\subsection{Bulgular}

Birim kurulu gücü $3.3 \mathrm{MW}$ olan 30 adet rüzgar türbininin NBD ait simülasyon sonuçlarına așağıda yer verilmiștir. Așağıdaki NBD ait sonuçlar, normal durumun dikkate alındığı senaryo sonuçlarıdır.

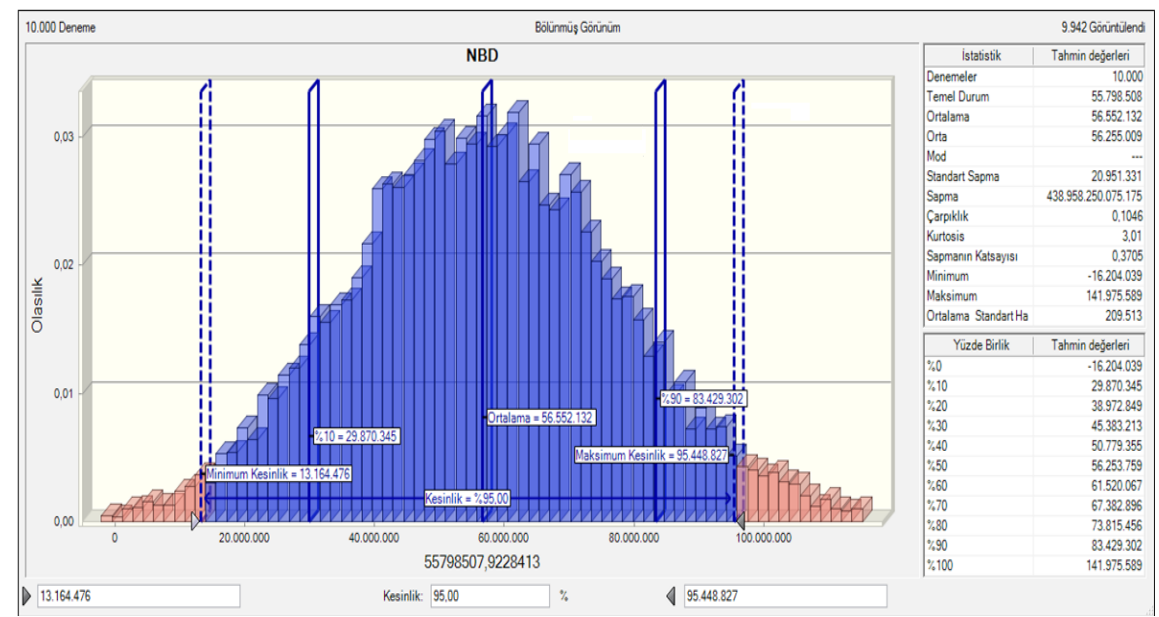

Șekil 4: RES Yatııımına Ait Projenin NBD'nin Tahmin Sonuçları

Șekil 4'te, Ek 2'de yer alan girdi bağımsız değișkenlerin dağılımlarına göre NBD'nin tahmin sonuçları sunulmuștur. NBD tahmin sonuçlarına bakıldığında ortalama olarak RES yatırımının NBD'si 56.552.132 Amerikan dolarıdır. \%95 kesinlik sınırları içerisinde RES yatırımının NBD'si minimum olarak 13.164.476 Amerikan doları ve maksimum olarak 95.448.827 Ameriakan dolarıdır. RES yatıımının \%10 olasılık değerinde NBD'si 29.870.345 Amerikan doları olup \%90 olasılık değerinde ise NBD 83.429.302 Amerikan dolarıdır. Normal durum senaryosunda RES yatırımının pozitif NBD'ye sahip olduğu görülmektedir. Bu durumda pozitif NBD yatırımın ekonomik olarak kazançlı olduğunu ve RES yatırımının bu girdi değișkenlere göre kabul edilebilir bir yatırım olduğunu göstermektedir. 


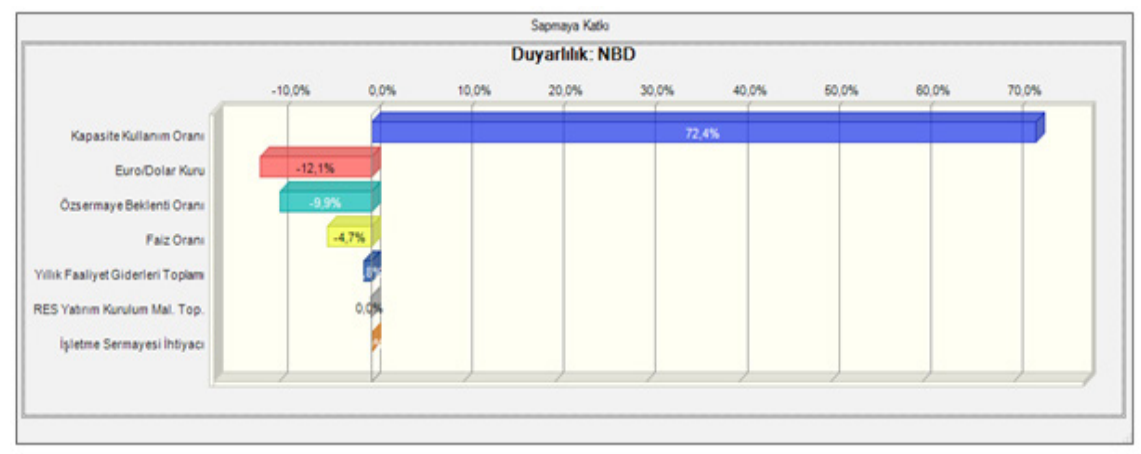

Șekil 5: RES Yatırım Projesinde NBD’ye Ait Duyarlılık Analizi Sonuçları

Șekil 5'te RES yatırımında NBD'yi etkileyen değișkenlerin duyarlılık sonuçları sunulmuștur. Kapasite kullanım oranı, yatırımın NBD'sini "\%72.4" ile pozitif yönde etkileyen en önemli parametredir. Ve kapasite kullanım oranının yatırımın NBD'sinde pozitif yönde bir etki, nakit giriși sağlayan parametrelerden biri olması beklenir. Kapasite kullanımı yatırım gelirini etkileyen önemli bir parametredir. RES yatırımında duyarlılık analizi sonuçlarında kapasitedeki artıșın yatırımın NBD'sini pozitif yönde etkilediği görülmektedir. Bir yatırımın NBD'si, nakit çıkıșına yol açan veya nakit çıkıșını artıran sebeplerden dolayı negatif yönde etkilenmektedir. Duyarlılık analizi sonuçlarında ikinci önemli etki "-\%12.1" ile Euro/Dolar kurundan kaynaklanmaktadır. Euro/Dolar kuru, türbin maliyetini etkileyen önemli bir değișkendir. Türbin temini euro cinsinden, gelir ise dolar cinsindendir. Euro/Dolar kurundaki artıș yatırımın NBD'sini negatif yönde etkilemektedir. Bir diğer duyarlılık değeri ise iskonto oranıdır. Yatırımın iskonto değeri de NBD'yi negatif etkilemektedir. Özsermaye maliyetindeki ve faiz oranındaki artıș NBD'yi negatif etkilemektedir. Özsermaye maliyeti "- \%9,9" ile faiz oranı da "-\%4,7" ile NBD'yi etkilemektedir. Bir diğer ifade ile RES yatırımının NBD'si "-\%9,9" ile özsermaye maliyetine ve "-\%4,7" ile de faiz oranına duyarlıdır. RES yatırmına ait NBD, yıllık faaliyet giderlerinden "-\%1,8" değerinde etkilenmektedir. RES yatırımına ait kurulum maliyeti toplamı ve ișletme sermayesi ihtiyacı yaklașık olarak "-\% 0.5" oranında NBD'yi etkilemektedir. Yatırım maliyetinin NBD'yi etkilemedeki duyarlılığı 
oldukça düșük çıkmıștır. Normal durum senaryosunda nakit akıșında en önemli parametrenin kapasite kullanım oranında olduğu görülmektedir. Yatııım yapılacak yerin kapasite kullanımını yüksek düzeyde tutacak daimi rüzgar gücüne sahip olması RES yatırımı için önem arz etmektedir. Her ne kadar ilk yatırım maliyetindeki artıș düșük çıkmıș olsa da yatırımın maliyet artırıcı olan euronun dolar karșısındaki değer artıșı yatııımın NBD'sini negatif etkileyen bir parametredir.

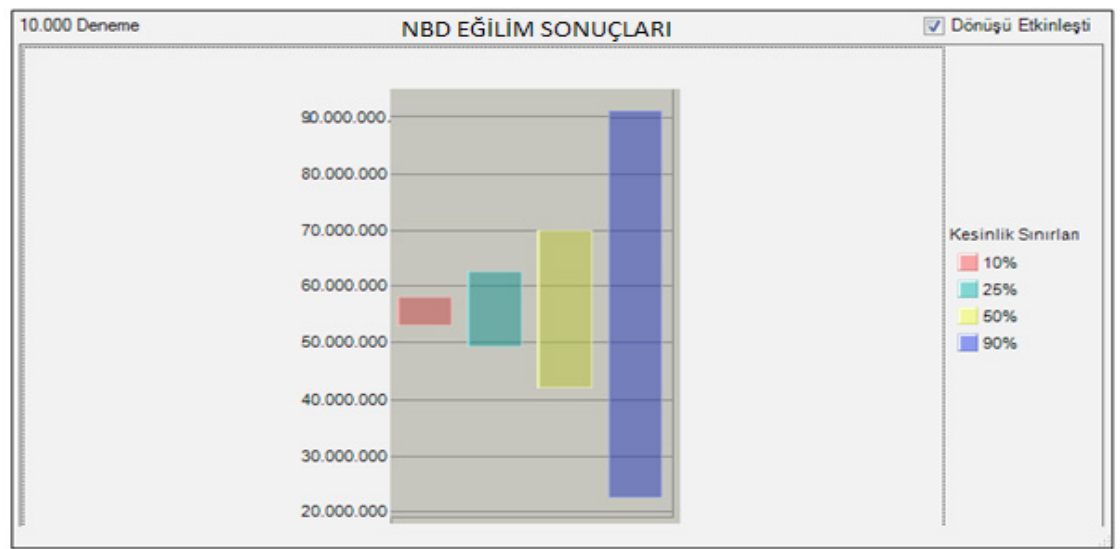

Șekil 6: RES Yatırım Projesinde NBD’ye Ait Eğilim Sonuçları

Șekil 6'da RES yatırım projesinin normal durum senaryosunda NBD'ye ait eğilim sonuçları sunulmuștur. Eğilim sonuçlarına göre \%10 kesinlik sınırları içerisinde yatırımın NBD'si yaklașık olarak 52.000.000 Amerikan doları ile 58.000.000 Amerikan doları aralığında, \%25 kesinlik sınırları içerisinde yatırımın NBD'si yaklașık olarak 49.000.000 Amerikan doları ile 61.000.000 Amerikan doları aralığında, \%50 kesinlik sınırları içerisinde yatırımın NBD'si yaklașık olarak 42.000.000 Amerikan doları ile 70.000.000 Amerikan doları aralığında, \%90 kesinlik sınırları içerisinde yatırımın NBD'si yaklașık olarak 24.000.000 Amerikan doları ile 92.000.000 Amerikan doları aralığındadır. RES Yatırım eğilim sonuçlarında NBD'nin mimimum değeri pozitif değerlere sahip olduğundan yatırımın ekonomik olarak kazançlı olduğunu göstermektedir. 
Șekil 7'de RES yatırım projesinde ki değișkenler arasındaki ilișkiyi gösteren matris sunulmuștur. Birinci satır ve sütünda bağımlı değișken olan NBD yer almaktadır. Matris içerisinde 7 adet bağımsız değișken bulunmaktadır. Bağımsız değișkenlerden kapasite kullanımı dıșında diğer değișkenlerin NBD ile negatif yönde bir ilișkiye sahip olduğu görülmektedir. Her bir matris kutucuğunda değișkenler arasındaki korelasyon derecesi de gösterilmiștir.

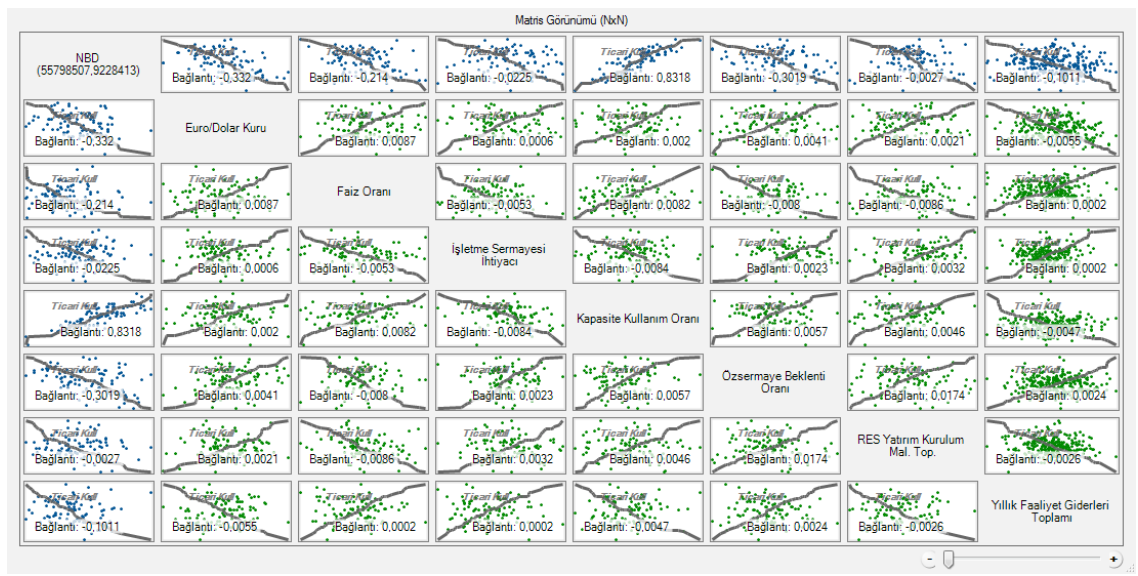

Șekil 7: RES Yatırım Projesinde Değișkenler Arasındaki İlișkiyi Gösteren Matris

Sekil 4-5-6-7'de RES yatırımının normal durum senaryosunda NBD için simülasyon analizi sonuçları sunulmuștur. Proje değerlendirmelerinde yatırım için tek bir durumu dikkate almak çoğu zaman yetersizdir. Yatırım değerlemesinde normal durum, iyi durum ve kötü durum gibi yatırım birden fazla durumdaki olası sonuçları dikkate alınarak yapılan değerlendirme daha sağlıklı karar verilmesi için önem arz etmektedir. Bu noktadan hareketle Tablo 1'de yatıımı etkileyen bağımsız değișkenlerin iyi durumları, normal durumları ve kötü durumları için olası değerler gösterilmiștir. 
Tablo 1: RES Yatırımını Etkileyen Bağımsız Değișkenlerin Farklı Senaryolarda Aldığı Değerler

\begin{tabular}{|l|c|c|c|}
\hline & Kötü Durum & $\begin{array}{c}\text { Temel Durum (Normal } \\
\text { Durum) }\end{array}$ & lyi durum \\
\hline Euro/Dolar Kuru & 1.35 & 1,26 & 1.15 \\
\hline Kapasite Kullanımı & $\% 30$ & $\% 40$ & $\% 50$ \\
\hline Faiz Oranı & $\% 9$ & $\% 7,5$ & $\% 6$ \\
\hline İșletme Sermayesi İhtiyacı & 150.000 & 100.000 & 50.000 \\
\hline Özsermaye Maliyeti & $\% 15$ & $\% 12$ & $\% 10$ \\
\hline Yıllık Faaliyet Giderleri Top. & $3.000 .000 \$$ & $2.400 .000 \$$ & $2.000 .000 \$$ \\
\hline RES Yatırımı Kur. Mal. Top. & $150.000 .000 \$$ & $120.000 .000 \$$ & $100.000 .000 \$$ \\
\hline
\end{tabular}

Tablo 1'de yer alan değișkenlere ait farklı senaryolardaki değerler Excel'de olușturulan finansal modelde ayrı ayrı simüle edilmiștir. Yatıım için üç farklı durumda (kötü durum, normal durum ve iyi durumda) yatırımın NBD'sine ait sonuçlara Tablo 1'de yer verilmiștir. NBD için tahmin değerlerine ait istatistiki sonuçlar ve yüzde birlik değerler yatırımın üç farklı durumu için hesaplanmıștır. Kötü durumda yatırımın NBD'sine ait değere bakıldığında negatif bir değere sahip olduğu görülmektedir. Kötü durumda yatırımın NBD'nin alacağı maksimum değerin pozitif olușu yatıımın kötü durumda değerlerinde iyi performans sergilemesi halinde kazançlı olduğunu göstermektedir. Yatırım için normal durum değerlendirmesinde ortalama NBD'nin 56.552.132 Amerikan doları olup pozitif bir değere sahip olduğu görülmektedir. Normal durumda yatırımın minimum NBD'nin negatif olduğu görülmektedir. Yatırımın iyi durum değerlendirmesinde sahip olduğu NBD'lerinin tamamının pozitif olduğu görülmektedir. Yatırım için girdi parametrelerinin iyi durumda RES yatırımının kesinlikle yapılması gerektiği ve kazançlı olduğunu göstermektedir. Üç durumun tamamı için NBD'ye ait dağılımın normal olduğu söylenebilir (Çarpıklık, Basıklık3). 
Tablo 2: Üç Farklı Senaryoda RES Yatırımının NBD Ait Simülasyon Sonuçları

\begin{tabular}{|c|c|c|c|c|}
\hline \multicolumn{2}{|c|}{ Tahmin Değerleri } & Kötü Durum & $\begin{array}{c}\text { Temel Durum (Normal } \\
\text { Durum) }\end{array}$ & İyi durum \\
\hline \multirow{7}{*}{ 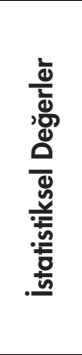 } & Sim. Deneme Say. & 10.000 Adet & 10.000 Adet & 10.000 Adet \\
\hline & Ortalama \$ & -16.756 .423 & 56.552 .132 & 143.987 .914 \\
\hline & Minimum \$ & -70.418 .953 & -16.204 .039 & 48.644 .813 \\
\hline & Maksimum \$ & 44.299 .541 & 141.975 .589 & 259.347 .056 \\
\hline & Standart Sapma \$ & 14.638 .571 & 20.951 .331 & 29.561 .276 \\
\hline & Çarpıklık & 0,131 & 0.104 & 0.105 \\
\hline & Basıklık & 3,02 & 3.01 & 2.95 \\
\hline \multirow{5}{*}{ 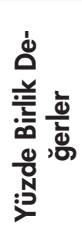 } & $\% 10$ & $-34.761 .823 \$$ & $29.870 .345 \$$ & $106.162 .376 \$$ \\
\hline & $\% 30$ & $-24.170 .347 \$$ & $45.383 .213 \$$ & $128.023 .430 \$$ \\
\hline & $\% 50$ & $-16.688 .306 \$$ & $56.253 .759 \$$ & $143.353 .872 \$$ \\
\hline & $\% 70$ & $-8.896 .277 \$$ & $67.382 .896 \$$ & $159.279 .352 \$$ \\
\hline & $\% 90$ & $2.679 .015 \$$ & $83.429 .302 \$$ & $182.699 .202 \$$ \\
\hline
\end{tabular}

Tablo 2'de tahmin değerlerinin yüzde birlik değerlerinde NBD'nin değerleri de yer almaktadır. Kötü durumda RES yatırımının yüzde birlik NBD'leri sadece \%90'da pozitif olup diğerlerinde negatif değere sahiptir. Normal durumda ve iyi durumda yatııımın yüzde birlik değerlerinin tamamında pozitif olduğu görülmektedir.

\section{Sonuç ve Değerlendirme}

Bu çalıșmada Türkiye'de kurulacak bir RES yatırımının finansal değerlendirmesi simülasyon yöntemi ile analiz edilmiștir. Bunun için bir finansal model olușturulmuș ve yatıımın projesine ait NBD hesaplanmıștır. Yatırım projelerini tek bir durumda değerlendirmek yetersiz olduğundan RES yatırımını için 3 farklı senaryoda yatırıma ait parametreler olușturulmuștur. Her bir senaryo için kurulan finansal modellemede yatırımın NBD'i Crystall Ball programı ile simüle edilmiștir. Simülasyon sonuçlarına göre yatırımın NBD'i kötü durum senaryosunda kabul edilmeyip yatırım yapılmama kararı alınabilir. Kötü durumda \%90 yüzde birlik değerde veya maksimum NBD durumunda RES yatıımının yapımı kabul edilebi- 
lir. RES yatırımı için normal durum senaryosunda yatırımın ortalama NBD'i pozitif olduğundan yatırımı yapmak ekonomik olarak anlamlıdır. Normal durum senaryosunda her ne kadar ortalama değer pozitif görünse de minimum değerin negatif olması RES yatırımcısı tarafından göz önünde bulundurulması gereken bir diğer sonuçtur. Normal duruma ait tahmin değerlerinde yüzde birlik değer sonuçlarına bakıldığında bütün değerlerde RES yatııımının NBD'sinin pozitif olduğu görülmektedir. RES yatıımı için iyi durum senaryosuna bakıldığında NBD'lerinin bütün tahmin değerlerinin pozitif olduğu ve yatırımın ekonomik olarak önemli düzeyde kazançlı olduğu görülmektedir.

Tüm bu sonuçlara göre uygun kapasitede üretimin yapılacağı bir RES yatııımının ekonomik olarak kazançlı olduğu görülmektedir. Yatırım değerlendirmesinin tek bir deneme ile yapılması yatırımcı için yanıltıcı olabilmektedir. Hele ki yatırıma ait maliyet değerleri ve gelir değerleri standart olmadığında yatııımcının tek bir sonuca bağlı kalarak yatırım yapması yanılııı olacaktır. RES yatırımlarında her ne kadar yatırım maliyeti belirli gibi gözükse de tam olarak standart değildir. Bunun nedeni RES yatırımı yapılacak yere ait yerel nedenler veya kurulum anında yașanan beklenmedik nakit çıkıșlarıdır. Bu faktörler RES yatırımlarının maliyetini belirsiz kılmaktadır. RES yatırımlarında özellikle elde edilecek gelir konusunda hiçbir standart değer yoktur. Bunun nedeni ise RES yatırımı üretimi büyük oranda yatırımın kurulu olduğu yerdeki rüzgar hızına bağlıdır. Bölgedeki rüzgar geçmiș ölçümlerle her ne kadar ortalama bir değere sahip olmuș olsa da, bölgedeki rüzgar için standart bir değer yoktur. Yıllar, aylar, haftalar, günler ve gün içi değerler itibariyle bölgedeki rüzgar hızı çeșitlilik göstermektedir. Bu durum da üretimin neticesinde RES yatırımına ait elektrik üretimi ve nihai olarak elektrik satıșından elde edilecek olan RES yatırım geliri de değișecektir. Tüm bu nedenlerden dolayı RES yatırımlarını tek bir durum için değil farklı senaryolar için birden fazla kombinasyonları da içine alan bir değerlendirme yaklașımı ile ele almak daha doğru sonuçlar verecektir.

Bu çalıșmada RES yatıımının deterministik olarak dikkate alınan girdi değișkenleri üç farklı senaryo için olușturulan stokastik 
bir yapı içerisinde simüle edilmiștir. Elde edilen sonuçlara göre yatırımcı karșılaștırma yaparak yatırım kararları verebilmektedir. Bu açıdan RES yatıımı gibi maliyet ve gelire ait belirsizliklerin olduğu durumlarda simülasyon analizi yapmak yatırımcı için farklı durum değerlerini bir sonuç içerisinde görmesi açısından önemlidir. Yapılan bu çalıșmada Türkiye'de kurulacak olan bir RES yatırımı simülasyon analizi ile değerlendirilmiștir. Sonuç olarak uygun koșulların sağlanması halinde RES yatıımlarının ekonomik olarak kazançlı olduğu sonucuna erișilmiștir. 


\section{KAYNAKLAR}

Ay, A. (2010). Energy Sources And Investment Project Assessment: A Case Study About Wind Energy In Turkey, Bahçeșehir üniversitesi, Yayımlanmıș Yüksek Lisans Tezi, İstanbul.

Desrochers, G., Blanchard, M., ve Sud, S., 1986, A Monte-Carlo simulation method for the economic assessment of the contribution of wind energy to power systems. IEEE Transactions on Energy Conversion, (4), 50-56.

Frølunde, S. G., \& Obling, P. E. (2010). Valuation models for wind farms under development.

GWEC, 2016, Global Wind Statistics Annual Market Update 2015, http:// www.gwec.net/wp-content/uploads/vip/GWEC-Global-Wind-2015Report_April-2016_22_04.pdf (Erișim: 14.10.2016)

Hamamcıoğlu, (2010). Rüzgar Enerii Kaynaklı Elektrik Üretiminin Teknik/Ekonomik Analizi ve Yöresel Uygulaması, Yıldız Teknik Üniversitesi, Yayımlanmıș Yüksek Lisans Tezi, İstanbul.

Hançerlioğulları, A., (2006). Monte Carlo Simülasyon Metodu ve MCNP Kod Sistemi, Kastamonu. Education Journal, 14(2), 545-546.

Hertzmark, D. I. (2007). Risk assessment methods for power utility planning. Energy Sector Management Assistance Program. The World Bank, Energy Sector Management Assistance Program (ESMAP), Washington D.C.

Khindanova, I. (2013). A Monte Carlo Model of a Wind Power Generation Investment. The Journal of Applied Business and Economics, 15(1), 94.

Liberman, E. J. (2003). A life cycle assessment and economic analysis of wind turbines using Monte Carlo simulation (No. Afıt/Gee/Env/03-16). Air Force Inst Of Tech Wright-Patterson Afb Oh School Of Engineerıng And Management.

Madlener, R., \& Wenk, C. (2008). Efficient investment portfolios for the Swiss electricity supply sector.

Roques, F. A., Nuttall, W. J., \& Newbery, D. M. (2006). Using probabilistic analysis to value power generation investments under uncertainty. University of Cambridge, Electricity Policy Research Group.

Ross, S. A., Westerfield, R. W. ve Jaffe, J., 2010, Corporate Finance, Ninth Edition, ISBN 978-007-131308-7, NewYork. McGraw-Hill/Irwin.

Simkins, B., \& Simkins, R. (2013). Energy finance and economics: Analysis and valuation, risk management, and the future of energy (Vol. 606). John Wiley \& Sons. 
Spinney, P. J., \& Watkins, G. C. (1996). Monte Carlo simulation techniques and electric utility resource decisions. Energy Policy, 24(2), 155-163.

TUREB, 2016, Türkiye Rüzgar Eneriisi İstatistik Raporu, http:// www.tureb. com.tr/files/yayinlar/temmuz_2016_istatistik.pdf (Erișim: 17.10.2016)

Williams, S. K., Acker, T., Goldberg, M., ve Greve, M. (2008). Estimating the economic benefits of wind energy projects using Monte Carlo simulation with economic input/output analysis. Wind Energy, 11 (4), 397-414.

Cardell, J. B., \& Anderson, C. L. (2010, January). Analysis of the system costs of wind variability through Monte Carlo simulation. In System Sciences (HICSS), 2010 43rd Hawaii International Conference on (pp. 1-8). IEEE. 


\section{Ek 1: Tahmin Değișkeni Olan NBD'nin (Bağımlı Değișken) Crytall Ball Programına Girilmesi}

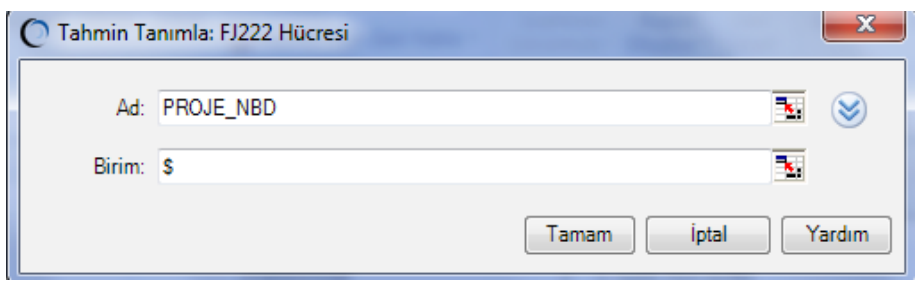

\section{Ek 2: Girdi Değișkenler ve Olasılık Dağılımları}

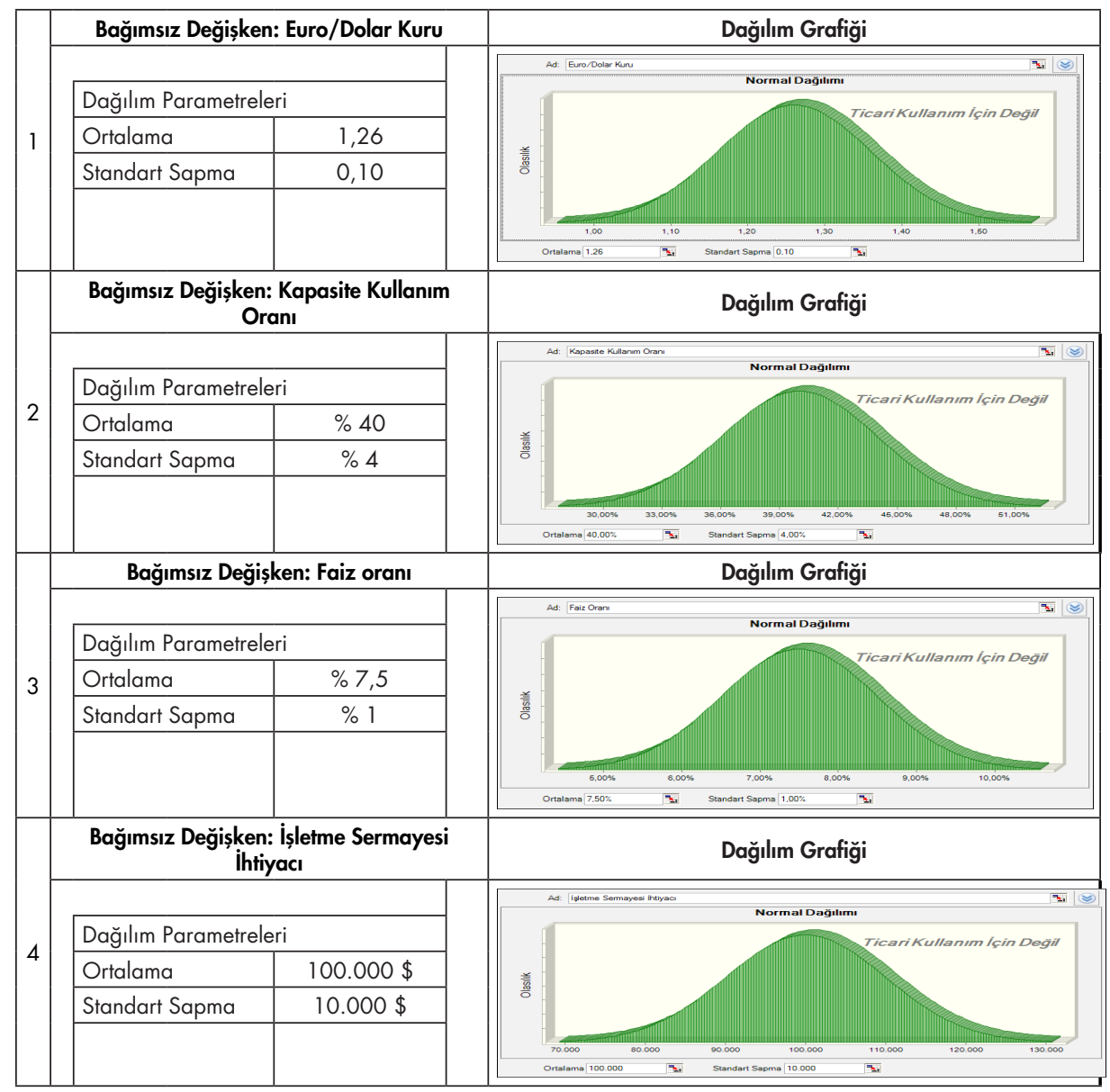




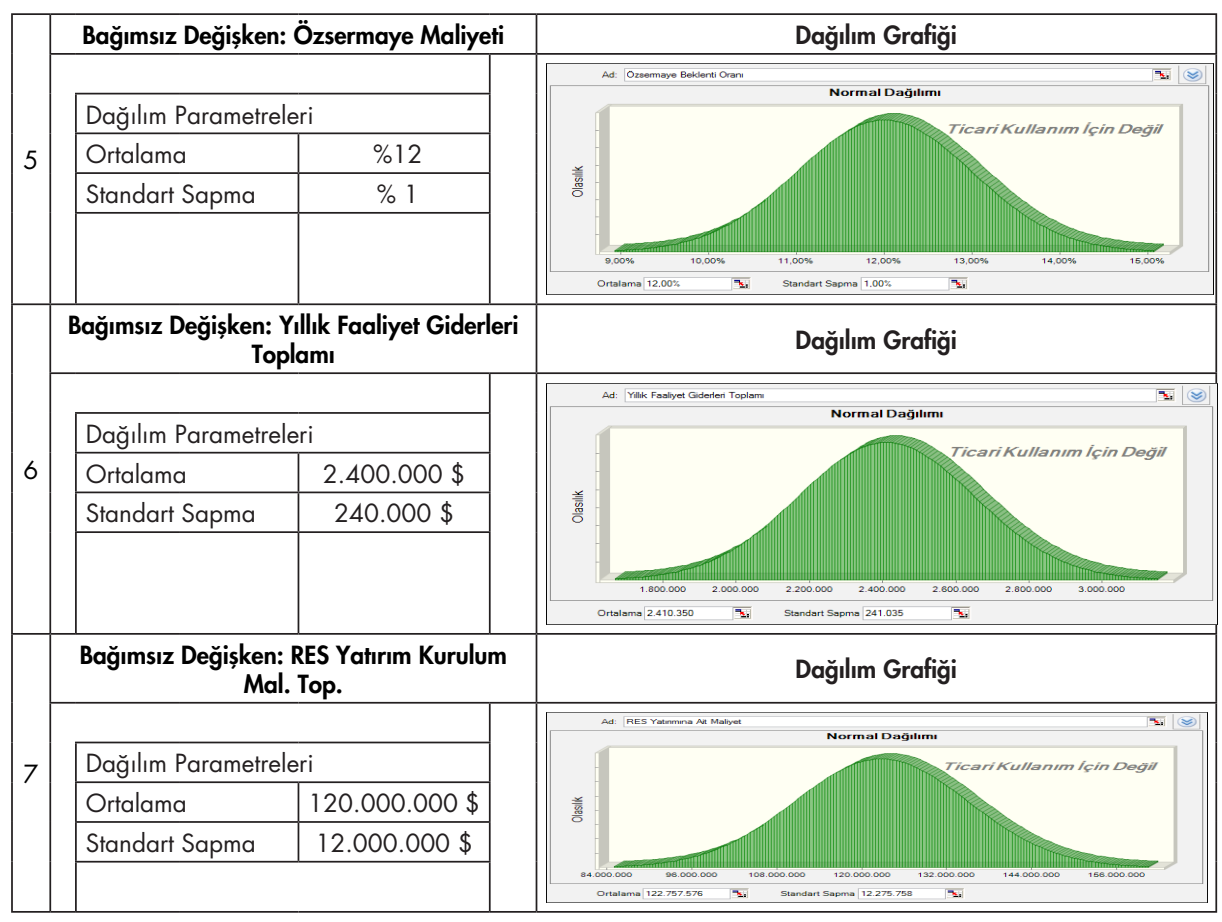

